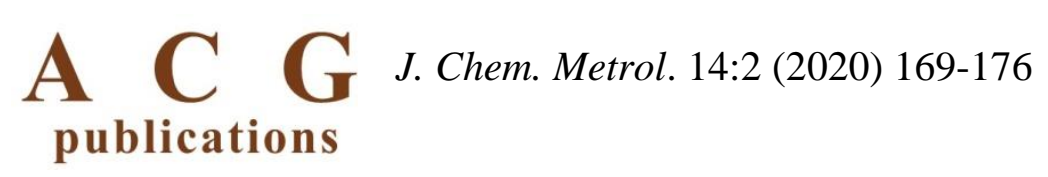

\title{
Assessment of the relationship between some physico-chemical properties of soil and soil algae in micro basin scale in Kocaeli
}

\author{
Arzu Morkoyunlu Yüce $\odot^{1 *}$ and Hüseyin Altundağ ${ }^{2}{ }^{2}$ \\ ${ }^{1}$ Kocaeli University, Hereke Asım Kocabiylk Vocational Schools, Departments of Environment and \\ Cleaning Services, 41000 Kocaeli, Turkiye \\ ${ }^{2}$ Sakarya University, Faculty of Arts and Sciences, Department of Chemistry,5400 Sakarya, Turkiye
}

(Received Month 12, 2020; Revised June 24, 2020; Accepted June 28, 2020)

\begin{abstract}
In this study, it was aimed to determine the relationship between soil algae and physico-chemical structure of soil. Algae composition and some soil quality parameters from 12 sampling stations were investigated between March 2019 and May 2019 in Kocaeli. Physico-chemical properties that reflect soil nutrient content and fertility status $\left(\mathrm{pH}\right.$, conductivity, salinity, $\mathrm{CaCO}_{3}$, organic matter, saturation, $\mathrm{P}_{2} \mathrm{O}_{5}$ and $\mathrm{K}_{2} \mathrm{O}$ ) were determined using standard physicochemical techniques. Average in soil parameters were determined as $\mathrm{pH}: 8.06$, conductivity: $5.79 \mu \mathrm{mhos} / \mathrm{cm}$, salinity: $0.22 \%, \mathrm{CaCO}_{3}: 9.98 \%$, organic matter: $1.70 \%$, saturation: $59.55 \%, \mathrm{P}_{2} \mathrm{O}_{5}: 3.16 \mathrm{~kg} / \mathrm{da}, \mathrm{K}_{2} \mathrm{O}: 93.92 \mathrm{~kg} / \mathrm{da}$. Algal flora of Kocaeli province was a total of 30 taxa, 14 taxa of Bacillariophyta, 3 taxa of Chlorophyta, 1 taxa of Charophyta and 12 taxa of Cyanobacteria were identified. The determined as the Chroococcus cohaerens, Limnococcus limneticus, Phormidium nigroviride, Oscillatoria limosa, Gomphonema olivaceum, Hantzschia amphioxys and Nitzschia brevissima most dominant taxa. These taxa have been identified in stations with high industrial activity. Bacillariophyta taxa were found in all months due to their ecological tolerance, while other species belong to spring. In this study, the species diversity were found similar in research stations.
\end{abstract}

Keywords: Soil; epipelic algae; ecology; micro basin; physico-chemical parameters @ 2020 ACG Publications. All rights reserved.

\section{Introduction}

Soil resources are very important for the sustainability of terrestrial ecosystem and food safety. The quality of soil is highly influential on the structure of food and soil biodiversity. Soil micro algae have an important role in organic matter cycle [1 - 3]. As photoautotrophs, microalgae constitute the basis of soil food nets and play a key role in soil development. Terrestrial algae are very important for increasing soil fertility, preventing wind-borne erosion and sustainable management of soil by identifying biodiversity. Changes in algal biodiversity enable biological monitoring of soil recovery during soil development. In the research was determined the importance of algal diversity in quality assessment of agricultural ecosystems and of land usage [4]. Algae have been utilized as biological assay organisms for anticipating crop reaction to both fertilizers and pesticides because of their biochemical similarity to higher plants and their fast generation time [5]. In the formation of soil structure, flow of matter in the ecosystem and nitrogen fixation,

${ }^{*}$ Corresponding author E-Mail: arzu.yuce@ kocaeli.edu.tr 
algae spreading in the soil are very important. In particular, Cyanobacteria members reduce water erosion from the wind by providing soil water balance. However, algae are used as indicator organisms in the determination of anthropogenic pollution [3,5-8 ]. Soil algae are affected by pesticides, industrial and domestic wastes. In general, most herbicides, fungicides, and soil fumigants are detrimental to soil algae while most insecticides are not. However, the physico-chemical properties of the soil are also very important for life. The climate, geological structure and population of the region are important factors affecting soil properties [9]. Physical properties of soil (soil color, soil texture, soil structure) and chemical properties of soil are very necessary for ecological cycle. However, increasing industrialization and population growth in recent years has caused adverse effects on the fertile land. In particular, the Kocaeli region is under the influence of industrial pollutants. Kocaeli region and in Turkey, soil physico-chemical structure, heavy metal ratios, determination of pollutants, although the development work carried out in the area of agricultural land, there is less research on soil algae [2, 10-18].

In this study we aimed to determine the algae taxa on soil physical and chemical properties in Kocaeli region. The study will be helpful for detecting changes in soil use, biodiversity conservation and in planning for the land utilization.

\section{Experimental}

\subsection{Materials and Methods}

Kocaeli is located between $40^{\circ} 51^{\prime} 11$ " North latitude and $29^{\circ} 52^{\prime} 53^{\prime \prime}$ East longitude of Marmara Region. The surface area of Kocaeli province is $3,418 \mathrm{~km}^{2}$. It is an important region of industry in Turkey [10].

\subsection{Research Stations}

The research was conducted between March 2019 and May 2019 at 12 stations in Kocaeli region. The coordinates of the sampling stations were given in Figure 1 and Table 1.

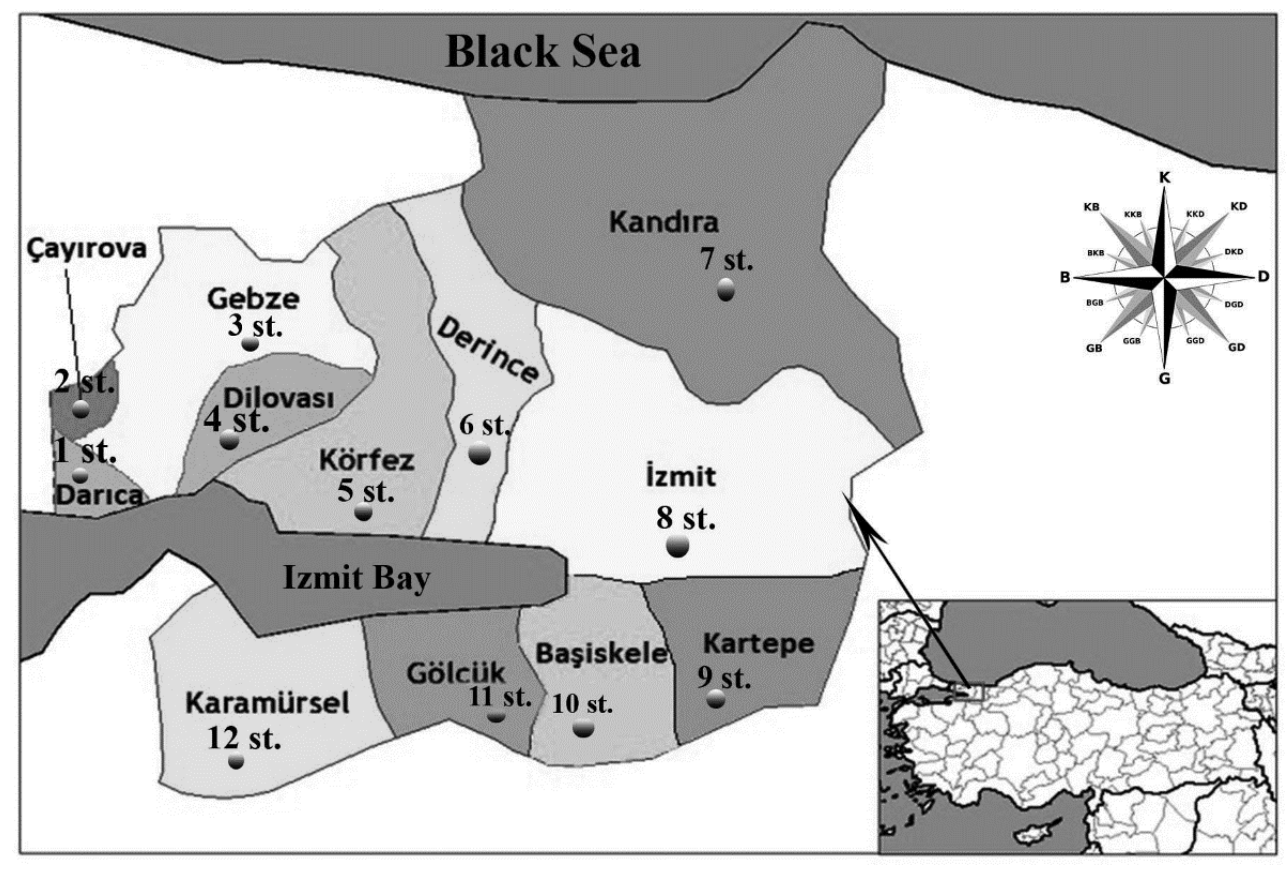

Figure 1. Research area and sampling stations (Turkey) 
Table 1. Coordinates of the sampling stations

\begin{tabular}{ccc}
\hline Stations & Regions & Coordinates \\
\hline 1 & Darica & $40^{\circ} 46.55 " \mathrm{~N}-29^{\circ} 22.12 " \mathrm{E}$ \\
2 & Cayirova & $40^{\circ} 50.10 " \mathrm{~N}-29^{\circ} 22.59^{\prime \prime} \mathrm{E}$ \\
3 & Gebze & $40^{\circ} 48.90 " \mathrm{~N}-29^{\circ} 26.23^{\prime \prime} \mathrm{E}$ \\
4 & Dilovas1 & $40^{\circ} 46.47 " \mathrm{~N}-29^{\circ} 32.06 " \mathrm{E}$ \\
5 & Körfez & $40^{\circ} 42.46 " \mathrm{~N}-29^{\circ} 44.30^{\prime \prime} \mathrm{E}$ \\
6 & Derince & $40^{\circ} 54.80 " \mathrm{~N}-29^{\circ} 54.17 " \mathrm{E}$ \\
7 & Kandira & $41^{\circ} 04.12 " \mathrm{~N}-30^{\circ} 09.01^{\prime \prime} \mathrm{E}$ \\
8 & Izmit & $40^{\circ} 45.55 " \mathrm{~N}-29^{\circ} 56.26 " \mathrm{E}$ \\
9 & Kartepe & $40^{\circ} 45.12 " \mathrm{~N}-30^{\circ} 1.23^{\prime \prime} \mathrm{E}$ \\
10 & Basiskele & $40^{\circ} 37.47 " \mathrm{~N}-29^{\circ} 57.03^{\prime \prime} \mathrm{E}$ \\
11 & Gölcük & $40^{\circ} 42.43 " \mathrm{~N}-29^{\circ} 50.28^{\prime \prime} \mathrm{E}$ \\
12 & Karamürsel & $40^{\circ} 41.21 " \mathrm{~N}-29^{\circ} 36.54 " \mathrm{E}$ \\
\hline
\end{tabular}

\subsection{Collection and Examination of Samples}

Kocaeli region is determined epipelic terrestrial algae and soil structure. Soil samples were taken between March 2019 and May 2019. Soil samples were taken vertically from the surface and just below the surface $(1-2 \mathrm{~cm}$.) using special perforated metal material. Physico chemical analysis of soils, $\mathrm{pH}$ (TS8332 ISO 10390), electrical conductivity (TS 8334), salinity (TS 8334), $\mathrm{CaCO}_{3}$ (TS EN ISO 10693), organic matter (TS 8336), saturation (TS 8333), $\mathrm{P}_{2} \mathrm{O}_{5}$ (TS 8340), $\mathrm{K}_{2} \mathrm{O}$ (TS 8341), according to standard techniques and methods were determined in the laboratory of Kocaeli Metropolitan Municipality. Soils for algae samples were placed in sterile petri dishes and moistened with sterile water. Lamels were placed on moist soil $(22 \times 22 \mathrm{~mm}$.). These samples were placed in a natural light area in the laboratory and left to stand for 24 hours. Algae adhering to the lamels by phototaxis were examined in transient preparations in $10 \%$ glycerin. Other soil suspension was boiled in $10 \% \mathrm{H}_{2} \mathrm{O}_{2}$ solution to remove any organic material and was repeatedly rinsed with distilled water to obtain cleaned diatom frustules $[19,16]$. The slides were examined using an Motic type 102M research microscope under $1600 \mathrm{X}$ magnification. Algae taxa were identified by using relevant books and literatures [20 - 29]. Current systematics of taxa were checked from databases [ 30,31]. However, correlation analysis was performed to determine the relationship of algae species with physico-chemical parameters. Statistical analyzes were performed in SPSS v.11.5 package program [32]. Redundancy analysis (RDA) was carried out using CANOCO software [33].

\section{Results and Discussion}

Soil algae species distributed in Kocaeli micro basin were investigated qualitatively and quantitatively. Algal flora of Kocaeli province, a total of 30 taxa, 14 taxa of Bacillariophyta, 3 taxa of Chlorophyta, 1 taxa of Charophyta and 12 taxa of Cyanobacteria were identified. Chroococcus cohaerens

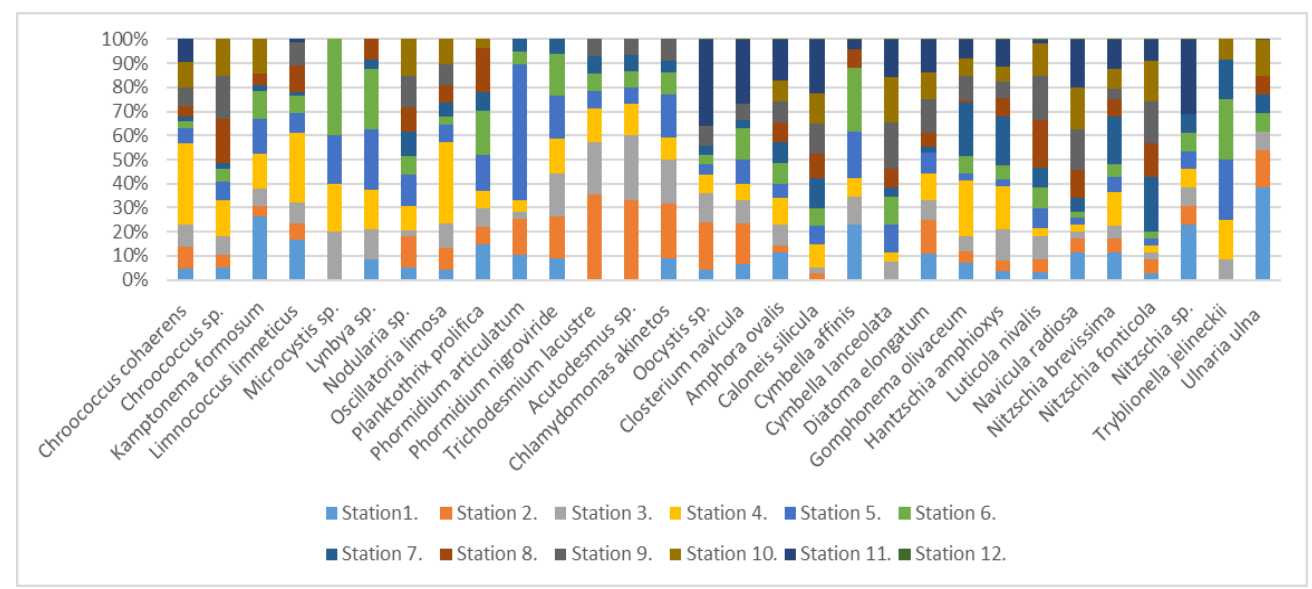

Figure 2. Taxa identified in the research $(\%)$ 
(Bréb.) Nägeli, Limnococcus limneticus (Lemmerm.) Komárk. et al., Phormidium nigroviride (Thwaites ex Gomont) Anagn. \& Komárek, Oscillatoria limosa C.Agardh ex Gomont, Gomphonema olivaceum (Horn.) Brébisson, Hantzschia amphioxys (Ehrenb.) Grunow and Nitzschia brevissima Grunow were most dominant taxa in the study. Identified taxa and $\%$ abundance rates were given in Table 2 and Figure 2 and, general soil characteristics of Kocaeli region were given in Table 3.

Table 2. The list of abundance of soil algae in Kocaeli region in stations 1-12

\begin{tabular}{|c|c|c|c|c|c|c|c|c|c|c|c|c|}
\hline Algae & 1 & 2 & 3 & 4 & 5 & 6 & 7 & 8 & 9 & 10 & 11 & 12 \\
\hline Cyanobacteria & & & & & & & & & & & & \\
\hline Chroococcus cohaerens (Bréb.) Nägeli & $\mathrm{R}$ & $\mathrm{R}$ & $\mathrm{C}$ & $\mathrm{D}$ & $\mathrm{C}$ & $\mathrm{R}$ & $\mathrm{R}$ & $\mathrm{R}$ & $\mathrm{R}$ & $\mathrm{R}$ & $\mathrm{R}$ & - \\
\hline Chroococcus sp. & $\mathrm{R}$ & $\mathrm{R}$ & $\mathrm{R}$ & $\mathrm{C}$ & $\mathrm{R}$ & $\mathrm{R}$ & $\mathrm{R}$ & $\mathrm{R}$ & $\mathrm{R}$ & $\mathrm{R}$ & - & - \\
\hline $\begin{array}{l}\text { Kamptonema formosum (Broy ex Strunecký, Komárek } \\
\& \text { J.Smarda }\end{array}$ & $\mathrm{C}$ & $\mathrm{R}$ & $\mathrm{R}$ & $\mathrm{C}$ & $\mathrm{R}$ & $\mathrm{R}$ & $\mathrm{R}$ & $\mathrm{P}$ & . & $\mathrm{R}$ & - & \\
\hline $\begin{array}{l}\text { Limnococcus limneticus (Lemmermann) Komárková, } \\
\text { Jezberová, O. Komárek \& Zapomelová }\end{array}$ & $\mathrm{C}$ & $\mathrm{R}$ & $\mathrm{R}$ & $\mathrm{D}$ & $\mathrm{C}$ & $\mathrm{R}$ & $\mathrm{R}$ & $\mathrm{R}$ & $\mathrm{R}$ & - & $\mathrm{R}$ & - \\
\hline Microcystis sp. & - & - & $\mathrm{R}$ & $\mathrm{R}$ & $\mathrm{R}$ & $\mathrm{R}$ & - & - & - & - & - & - \\
\hline Lynbya sp. & $\mathrm{R}$ & $\mathrm{R}$ & $\mathrm{R}$ & $\mathrm{R}$ & $\mathrm{R}$ & $\mathrm{R}$ & $\mathrm{R}$ & $\mathrm{R}$ & - & - & - & - \\
\hline Nodularia sp. & $\mathrm{R}$ & $\mathrm{R}$ & $\mathrm{R}$ & $\mathrm{R}$ & $\mathrm{R}$ & $\mathrm{R}$ & $\mathrm{R}$ & $\mathrm{R}$ & $\mathrm{R}$ & $\mathrm{R}$ & - & - \\
\hline Oscillatoria limosa C.Agardh ex Gomont & $\mathrm{R}$ & $\mathrm{R}$ & $\mathrm{R}$ & $\mathrm{D}$ & $\mathrm{C}$ & $\mathrm{R}$ & $\mathrm{R}$ & $\mathrm{R}$ & $\mathrm{R}$ & $\mathrm{R}$ & - & - \\
\hline $\begin{array}{l}\text { Planktothrix prolifica(Gomont) Anagnostidis \& } \\
\text { Komárek }\end{array}$ & $\mathrm{R}$ & $\mathrm{R}$ & $\mathrm{R}$ & $\mathrm{R}$ & $\mathrm{R}$ & $\mathrm{R}$ & $\mathrm{R}$ & $\mathrm{R}$ & . & $\mathrm{R}$ & - & 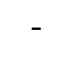 \\
\hline $\begin{array}{l}\text { Phormidium articulatum (N.L.Gardner) Anagn. \& } \\
\text { Komárek }\end{array}$ & $\mathrm{R}$ & $\mathrm{R}$ & $\mathrm{R}$ & $\mathrm{R}$ & $\mathrm{R}$ & $\mathrm{R}$ & $\mathrm{R}$ & - & - & . & - & - \\
\hline $\begin{array}{l}\text { Phormidium nigroviride (Thwaites ex Gomont) } \\
\text { Anagn. \& Komárek }\end{array}$ & $\mathrm{R}$ & $\mathrm{R}$ & $\mathrm{R}$ & $\mathrm{D}$ & $\mathrm{R}$ & $\mathrm{R}$ & $\mathrm{R}$ & - & - & - & - & - \\
\hline $\begin{array}{l}\text { Trichodesmium lacustre Kleb. } \\
\text { Chlorophyta }\end{array}$ & - & $\mathrm{R}$ & $\mathrm{R}$ & $\mathrm{R}$ & $\mathrm{R}$ & $\mathrm{R}$ & $\mathrm{R}$ & - & $K$ & - & - & - \\
\hline Acutc & - & $\mathrm{R}$ & $\mathrm{R}$ & $\mathrm{R}$ & $\mathrm{R}$ & & & - & & & & - \\
\hline s akinetos Deason \& Bold & $\mathrm{R}$ & $\mathrm{R}$ & $\mathrm{R}$ & $\mathbf{R}$ & $\mathrm{R}$ & $\mathrm{r}$ & $\mathrm{H}$ & - & & & - & - \\
\hline & $\mathrm{R}$ & 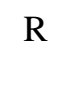 & $\mathrm{R}$ & $\mathrm{R}$ & $\mathrm{R}$ & $\mathrm{R}$ & $\mathrm{R}$ & - & $\mathrm{R}$ & - & $\mathrm{R}$ & - \\
\hline $\begin{array}{l}\text { avicula (Bréb.) Lütkem. } \\
\text { yta }\end{array}$ & $\mathrm{R}$ & $\mathrm{R}$ & $\mathrm{R}$ & $\mathrm{R}$ & $\mathrm{R}$ & $\mathrm{R}$ & $\mathrm{R}$ & - & $\mathrm{R}$ & - & $\mathrm{R}$ & - \\
\hline (Kütz.) Kütz. & $\mathrm{R}$ & $\mathrm{R}$ & $\mathrm{R}$ & c & $\mathrm{R}$ & $\mathrm{R}$ & $\mathrm{R}$ & $\mathrm{F}$ & $\mathrm{E}$ & $\mathrm{R}$ & $\mathrm{R}$ & $\mathrm{R}$ \\
\hline $\begin{array}{l}\text { Brebissonia lanceolata (C.Agardh) R.K.Mahoney \& } \\
\text { Reimer }\end{array}$ & - & - & $\mathrm{R}$ & $\mathrm{R}$ & $\mathrm{R}$ & $\mathrm{R}$ & $\mathrm{R}$ & $\mathrm{K}$ & $\mathrm{R}$ & $\mathrm{R}$ & $\mathrm{R}$ & $\mathrm{R}$ \\
\hline Caloneis silicula (Ehrb.) Cleve & - & $\mathrm{R}$ & $\mathrm{R}$ & K & $\mathrm{R}$ & $\mathrm{R}$ & K & & $\mathrm{R}$ & $\mathrm{R}$ & K & $\mathrm{R}$ \\
\hline Cyl & $\mathrm{R}$ & - & $\mathrm{R}$ & $\mathrm{R}$ & $\mathrm{R}$ & $\mathrm{R}$ & - & $\mathrm{l}$ & - & - & $\mathrm{R}$ & $\mathrm{R}$ \\
\hline gatum C.A Agarc & $\mathrm{R}$ & $\mathrm{R}$ & $\mathrm{R}$ & $\mathrm{C}$ & $\mathrm{R}$ & - & $\mathrm{R}$ & 10 & $\mathrm{~K}$ & $\mathrm{R}$ & $\mathrm{R}$ & $\mathrm{R}$ \\
\hline Gomp & $\mathrm{R}$ & $\mathrm{R}$ & $\mathrm{R}$ & $\mathrm{D}$ & $\mathrm{R}$ & $\mathrm{C}$ & $\mathrm{D}$ & 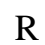 & & $\mathrm{R}$ & $\mathrm{R}$ & $\mathrm{R}$ \\
\hline runow & $\mathrm{R}$ & $\mathrm{R}$ & $\mathrm{C}$ & 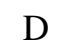 & - & $\mathrm{R}$ & $\mathrm{D}$ & & & & & $\mathrm{R}$ \\
\hline Iann & $\mathrm{R}$ & $\mathrm{R}$ & $\mathrm{R}$ & $\mathrm{R}$ & $\mathrm{R}$ & $\mathrm{r}$ & $\mathrm{r}$ & I & ( & & $\mathrm{C}$ & $\mathrm{C}$ \\
\hline & $\mathrm{R}$ & $\mathrm{R}$ & $\mathrm{R}$ & $\mathrm{R}$ & $\mathrm{R}$ & $\mathrm{R}$ & $\mathrm{F}$ & $\mathrm{r}$ & $\mathrm{F}$ & $\mathrm{r}$ & $\mathrm{R}$ & $\mathrm{R}$ \\
\hline & $\mathrm{R}$ & $\mathrm{R}$ & $\mathrm{R}$ & $\mathrm{D}$ & $\mathrm{R}$ & $\mathrm{K}$ & $\mathrm{L}$ & 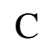 & & ( & $\mathrm{D}$ & $\mathrm{C}$ \\
\hline ticola (Grunow) Grunow & $\mathrm{R}$ & $\mathrm{R}$ & $\mathrm{R}$ & $\mathrm{R}$ & $\mathrm{R}$ & $\mathrm{R}$ & $\mathrm{R}$ & $\mathrm{R}$ & $\mathrm{R}$ & $\mathrm{R}$ & $\mathrm{R}$ & $\mathrm{C}$ \\
\hline Nitzsc & $\mathrm{R}$ & $\mathrm{R}$ & $\mathrm{R}$ & $\mathrm{R}$ & $\mathrm{R}$ & $\mathrm{R}$ & $\mathrm{R}$ & 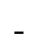 & 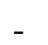 & - & $\mathrm{R}$ & $\mathrm{R}$ \\
\hline Trybli & - & - & $\mathrm{R}$ & $\mathrm{R}$ & $\mathrm{F}$ & & $\mathrm{k}$ & & & & - & - \\
\hline Ulnaria ulna (Nitzsch) Compère & $\mathrm{R}$ & $\mathrm{R}$ & $\mathrm{R}$ & $\mathrm{R}$ & $\mathrm{R}$ & $\mathrm{R}$ & $\mathrm{R}$ & $\mathrm{R}$ & & $\mathrm{R}$ & - & $\mathrm{R}$ \\
\hline
\end{tabular}

*Abundance: D: Dominant (>20\%); C: Common (10-20\%); R: Rare (<10\%); -: Not found. 
Table 3. Soil properties of Kocaeli region

\begin{tabular}{|c|c|c|c|c|c|}
\hline Parameters & $\begin{array}{l}\text { Analysis } \\
\text { method }\end{array}$ & Units & $\begin{array}{c}\text { Determined } \\
\text { value }\end{array}$ & Result & $\begin{array}{l}\text { Reference } \\
\text { value }\end{array}$ \\
\hline $\mathrm{pH}$ & $\begin{array}{c}\text { TS8332 } \\
\text { ISO } 10390\end{array}$ & - & 8.06 & $\begin{array}{l}\text { Slightly } \\
\text { alkaline }\end{array}$ & $7.5-8.5$ \\
\hline Electrical conductivity & TS 8334 & $\mu \mathrm{mhos} / \mathrm{cm}$ & 5.79 & light salty & $4-8$ \\
\hline Salinity & TS 8334 & $\%$ & 0.22 & light salty & $0.5-0.35$ \\
\hline $\mathrm{CaCO}_{3}$ & $\begin{array}{c}\text { TS EN ISO } \\
10693\end{array}$ & $\%$ & 9.98 & Limy & $1-5$ \\
\hline Organic matter & TS 8336 & $\%$ & 1.70 & Little & $1-2$ \\
\hline Saturation & TS 8333 & $\%$ & 59.55 & Argillaceous & $51-70$ \\
\hline $\mathrm{P}_{2} \mathrm{O}_{5}$ & TS 8340 & $\mathrm{~kg} / \mathrm{da}$ & 3.16 & Little & $\leq 3$ \\
\hline $\mathrm{K}_{2} \mathrm{O}$ & TS 8341 & $\mathrm{~kg} / \mathrm{da}$ & 93.92 & High & $>40$ \\
\hline
\end{tabular}

Spearman correlation coefficients of soil quality parameters were given in Table 4. A positive correlation was found between salinity - conductivity, $\mathrm{P}_{2} \mathrm{O}_{5^{-}}$salinity, $\mathrm{P}_{2} \mathrm{O}_{5^{-}}$organic matter, $\mathrm{K}_{2} \mathrm{O}$ - Organic matter and $\mathrm{K}_{2} \mathrm{O}-\mathrm{P}_{2} \mathrm{O}_{5}(\mathrm{p}<0.05)$. Negative correlation was determined between saturation $-\mathrm{CaCO}_{3}$, $\mathrm{pH}-$ salinity and $\mathrm{pH}-\mathrm{P}_{2} \mathrm{O}_{5}(\mathrm{p}<0.05)$.

Table 4. Spearman correlation coefficients in soil parameters

\begin{tabular}{|c|c|c|c|c|c|c|c|c|}
\hline $\begin{array}{c}\text { Soil } \\
\text { parameters }\end{array}$ & Conductivity & Salinity & $\mathrm{CaCO}_{3}$ & $\begin{array}{c}\text { Organic } \\
\text { matter }\end{array}$ & Saturation & $\mathbf{P}_{2} \mathbf{O}_{5}$ & $\mathrm{~K}_{2} \mathrm{O}$ & pH \\
\hline Conductivity & 1.000 & & & & & & & \\
\hline Salinity & $0.967 *$ & 1.000 & & & & & & \\
\hline $\mathrm{CaCO}_{3}$ & 0.266 & 0.138 & 1.000 & & & & & \\
\hline $\begin{array}{l}\text { Organic } \\
\text { matter }\end{array}$ & -0.223 & -0.207 & -0.202 & 1.000 & & & & \\
\hline Saturation & -0.063 & 0.159 & $-0.451^{*}$ & 0.034 & 1.000 & & & \\
\hline $\mathrm{P}_{2} \mathrm{O}_{5}$ & 0.358 & $0.404 *$ & 0.262 & $0.504 *$ & 0.198 & 1.000 & & \\
\hline $\mathrm{K}_{2} \mathrm{O}$ & 0.042 & 0.140 & 0.091 & $0.545^{*}$ & 0.047 & $0.768^{*}$ & 1.000 & \\
\hline $\mathrm{pH}$ & -0.384 & $-0.566^{*}$ & 0.344 & -0.196 & -0.630 & $-0.426^{*}$ & 0.123 & 1.000 \\
\hline
\end{tabular}

*Values indicate that there is strong statistical relationship $(\mathrm{p}<0.05)$

To determine the relationship between the biomass of the most abundant algae, sampling period and environmental variables, RDA was carried out on the log-normal transformed abundance data. Statistical significance of the environmental predictor variables was assessed by 999 restricted Monte Carlo permutations. To analyze the relationship between epipelic algae distribution and environmental variables were performed in RDA. If the value of the first axis is less than 3, the taxa data is homogeneous and the RDA ordination method is used. The horizontal axis is the primary RDA axis, and the vertical axis is the second ordination axis. The eigenvalues of RDA axis $1(0.42)$ and axis $2(0.08)$, account for $51.47 \%$ of the cumulative variance in the epipelic algae. The most abundant algae and environmental correlations of RDA axis 1 and 2 are high and two-axis account for $85.97 \%$ of the variance in the most abundant algae and environmental relationships. Nitzschia brevissima, Gomphonema olivaceum, Oscillatoria limosa, Phormidium nigroviride, and Hantzschia amphioxys were positively correlated with conductivity and salinity while Chroococcus cohaerens and Limnococcus limneticus were positively correlated with $\mathrm{P}_{2} \mathrm{O}_{5}$. Phosphorus was determined to be more effective in the development of these species. The results of RDA was given in Figure 3. 


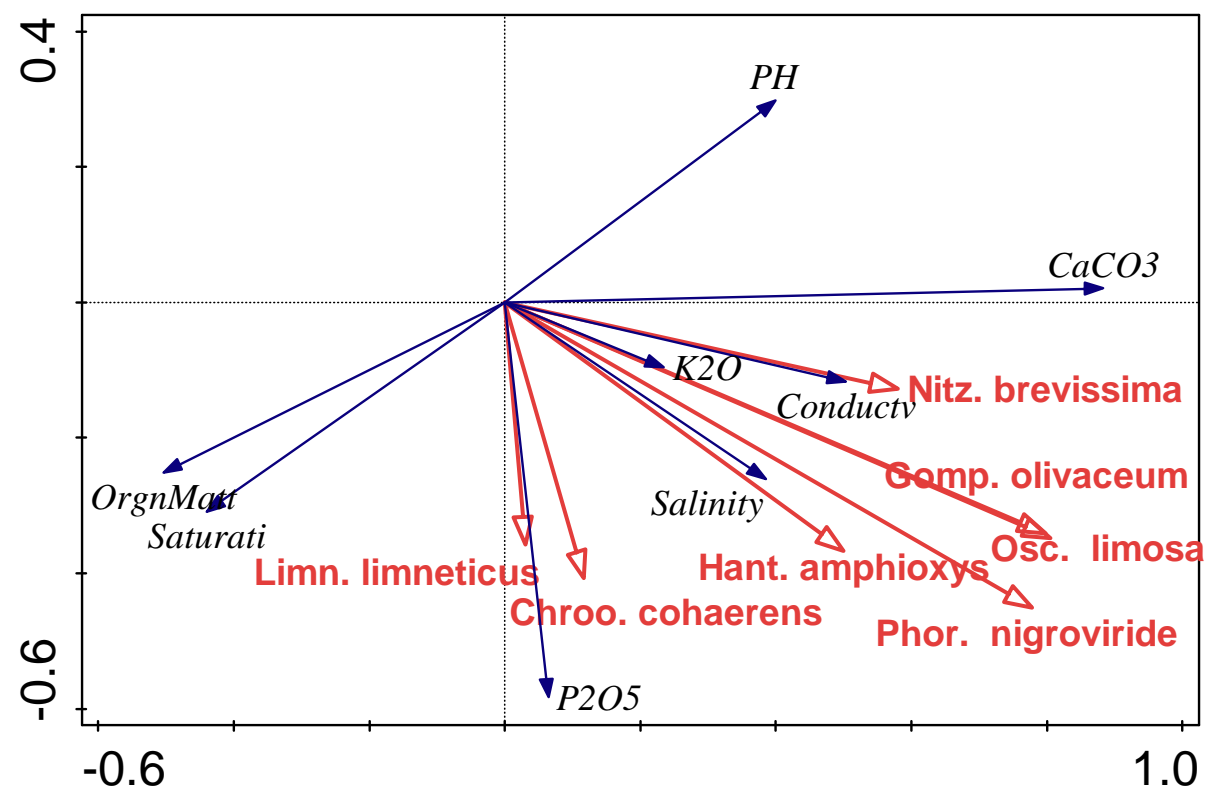

Figure 3. Multiplicity analysis for environmental variables and dominant taxa (RDA) in research area

Environmental factors are very important on the diversity of soil algae. Such activities (pesticides, herbicides, air pollution, population, heavy industry, other factors) affect the physico-chemical environment of soils and thus reduce the diversity of soil algae. In studied Kocaeli micro basin, the community structure of soil algae varied significantly from type to type, with Shannon diversity index ranging between 2.79 and 3.22, evenness index between 0.61 and 0.91 and Simpson's index between 0.91 and 0.95 (Table 5). The Simpson diversity index is generally similar to the Shannon-Weaver index. According to the Simpson and Shannon-Weaver index, it was concluded that the dominance was low and the number of species was high. However, it was determined that the soil has medium quality according to index values.

Table 5. Diversity indices of soil algae in stations 1-12

\begin{tabular}{lcccccccccccc}
\hline Index & $\mathbf{1}$ & $\mathbf{2}$ & $\mathbf{3}$ & $\mathbf{4}$ & $\mathbf{5}$ & $\mathbf{6}$ & $\mathbf{7}$ & $\mathbf{8}$ & $\mathbf{9}$ & $\mathbf{1 0}$ & $\mathbf{1 1}$ & $\mathbf{1 2}$ \\
\hline $\begin{array}{l}\text { Shannon } \\
\text { diversity index }\end{array}$ & 2.91 & 3.10 & 3.22 & 3.18 & 3.23 & 3.18 & 2.83 & 2.80 & 2.84 & 2.79 & 2.58 & 2.63 \\
$\begin{array}{l}\text { Evenness index } \\
\text { Simpson index }\end{array}$ & 0.75 & 0.95 & 0.84 & 0.80 & 0.84 & 0.83 & 0.61 & 0.82 & 0.86 & 0.91 & 0.83 & 0.84 \\
& 0.95 & 0.95 & 0.95 & 0.95 & 0.95 & 0.91 & 0.93 & 0.93 & 0.93 & 0.91 & 0.91 \\
\hline
\end{tabular}

\section{Conclusion}

This study was conducted in Kocaeli micro basin between March 2019 - May 2019. Average in soil parameters were determined as $\mathrm{pH}: 8.06$, Conductivity: $5.79 \mu$ mhos $/ \mathrm{cm}$, salinity: $0.22 \%$, $\mathrm{CaCO}_{3}$ : $9.98 \%$, organic matter: $1.70 \%$, saturation: $59.55 \%, \mathrm{P}_{2} \mathrm{O}_{5}: 3.16 \mathrm{~kg} / \mathrm{da}, \mathrm{K}_{2} \mathrm{O}: 93.92 \mathrm{~kg} / \mathrm{da}$. Soil structure of Kocaeli region is generally determined as slightly alkaline, light salty, limy and argillaceous. Organic matter and $\mathrm{P}_{2} \mathrm{O}_{5}$ values were determined as very low and $\mathrm{K}_{2} \mathrm{O}$ values were high. Spearman correlation coefficients of soil quality parameters were determined as positive correlation between salinity conductivity, $\mathrm{P}_{2} \mathrm{O}_{5}$ - salinity, $\mathrm{P}_{2} \mathrm{O}_{5}$ - organic matter, $\mathrm{K}_{2} \mathrm{O}$ - Organic matter and $\mathrm{K}_{2} \mathrm{O}-\mathrm{P}_{2} \mathrm{O}_{5}(\mathrm{p}<0.05)$. Negative correlation was determined between saturation $-\mathrm{CaCO}_{3}, \mathrm{pH}-$ salinity and $\mathrm{pH}-\mathrm{P}_{2} \mathrm{O}_{5}(\mathrm{p}<0.05)$. The soil algal flora at 12 stations chosen on Kocaeli micro basin were investigated between March 2019 and May 2019. The flora consisted of 30 taxa belonging to the Bacillariophyta, Chlorophyta, Cyanobacteria and Charophyta divisions. The species of Chroococcus cohaerens, Limnococcus limneticus, Phormidium nigroviride, Oscillatoria limosa, Gomphonema olivaceum, Hantzschia amphioxys and Nitzschia brevissima were observed to be abundant and frequent, in the months when the research was carried out. 
The other members of divisions were determined in various frequencies in the stations. As a result, Bacillariophyta was dominant among the soil algal flora of Kocaeli region. These species were identified especially in Dilovası and surrounding stations where industrial activities were intense. Of these taxa, $C$. cohaerens, C. akinetos, are a true soil algae species was identified in terrestrial habitats in Asia, the Arctic, Europe, America, Australia and New Zealand [31]. These species are cosmopolitan and widespread in various types of soils in literature [34]. In the study, species other than the real soil algae, Turkey was also determined in aquatic ecosystems [30,35]. In the soil samples around Lake Salty (Turkey) that Chroococcus varius, Phormidium agustissimum, Nitzschia vermicularis, Hantzschia species were determined and similar genera were determined in the soil algae of Kocaeli region $[11,15,16]$. In the study, the most abundant species and their relationship with environmental factors were detemined such as Nitzschia brevissima, Gomphonema olivaceum, Oscillatoria limosa, Phormidium nigroviride, Hantzschia amphioxys were positively correlated with conductivity and salinity. However, Chroococcus cohaerens and Limnococcus limneticus species also showed positive correlation with $\mathrm{P}_{2} \mathrm{O}_{5}$. It was determined that conductivity, salinity and phosphorus are highly effective in the development of these species. In the study, it was determined that the species diversity of the stations showed similar values and that the stations were medium species diversity.

In this study, it was determined that soil algae was under the influence of industrial pollutants. It was concluded that domestic and industrial pollutant pressures on soils should be reduced. As future research leads to awareness of soil algae importance, it might be expected that agricultural systems and agricultural practices will become more benefits.

\section{ORCID}

Arzu Morkoyunlu Yüce : 0000-0002-3678-4930

Huseyin Altundağ: 0000-0002-3675-4133

\section{References}

[1] K. Akhtar and S.R. Rehman (2009). Some members of ulotrichales from Jalala, district Mardan, Pak. J. Pl. Sci. 15, 19-30.

[2] G. Başbülbül, H. Bıyık, F. Kalyoncu, E. Kalmış and E. Oryasın (2011). Determination of microfungi flora of soil polluted by industrial wastewater in Aydın, İzmir and Manisa city, J. Ecol. 20, 66-73.

[3] S. Zancan, R. Trevisan and M.G. Paoletti (2006). Soil algae composition under different agro-ecosystems in North-Eastern Italy, Agric. Ecosyst. Environ. 112, 1-12.

[4] A.A. Alabi, A.O. Adewale, B. Adebo, A.S. Ogungbe, J.O. Coker, F.G. Akinboro and G. Bolaji (2019). Effects of different land uses on soil physical and chemical properties in Odeda LGA, Ogun State, Nigeria, Environ . Earth Sci. 78, 207. https://doi.org/10.1007/s12665-019-8205-4.

[5] B. Metting (1981). The systematics and ecology of soil algae, The Botan. Rev. 47, 195-312.

[6] J.R. Johansen (1993). Cryptogamic crusts of semiarid and arid lands of North America, J. Phycol. 29, 140147.

[7] A. Ozalap, S. Yılmaz, C. Ertekin and I. Y1lmaz (2018). Energy analysis and emissions of greenhouse gases of pomegranate production in Antalya province of Turkey, Erwerbs-Obstbau 60, 321-329.

[8] D.J. Patzel, L. Hodač, T. Friedl, N. Pietrasiak and J.R. Johansen (2014). Biodiversity of soil cyanobacteria in the hyper-arid Atacama Desert, Chile, J. Phycol. 50, 698-710.

[9] A. Kiflu and S. Beyene (2013). Effects of different land use systems on selected soil properties in South Ethiopia, J. Soil Sci. Environ. Manag. 4, 100-107.

[10] Anonymous (2018). Kocaeli province environmental status report. Kocaeli Provincial Directorate of Environment and Urbanization publications, Kocaeli, Turkey.

[11] T. Atıcı, O. Obalı, C. Akköz and A. Elmacı (2001). Isolation and identification of halophytic algae from salty soil around Salt Lake of Turkey, Pak. J. Biol. Sci. 4, 298-300.

[12] V. Aysel, U. Gezerler and H. Güner (1988). Soil Algae, IX. National Biology Congress Journal 3, 199-208.

[13] V. Aysel, G. Aykulu, A.N. Bakan and U. Gezerler-Şipal (1998). Algae developed in reconstituted raw soil culture, XIV. National Biol. Congr. J. 2, 304-313.

[14] H. Başar, S. Gürel and A.V. Katkat (2004). Heavy metal content of soils irrigated with different water resources in Iznik Lake basin. Uludağ Univ. J. Fac.Agric. 18, 93-104.

[15] N. Erener, M. Yazgan and V. Aysel (1995). Aquatic macro and micro algae growing in diluted garden soil with and without additives in laboratory conditions, Ege Univ. J. Fisher. 12, 125-134. 
[16] A. Morkoyunlu Yüce (2017). Soil Algae of the Körfez Region (Kocaeli/Türkiye), Biolog. Divers. Conserv. 10, 72-75.

[17] E. Osman, M. Serin, Z. Leblebici and A. Aksoy (2012). Heavy metals accumulation in some vegetables and soils in Istanbul, J. Ecol. 21, 1-8.

[18] F.E. Round, R.M. Crawford and D.G. Mann (1990). Diatoms: biology and morphology of the genera, Cambridge University Press 760.

[19] Y. Fujita and T. Ohtsuka (2005). Diatoms from paddy fields in northern Laos, Diatom 21, 71-89.

[20] L. Hodac (2016). Green algae in soil: assessing their biodiversity and biogeography with molecularphylogenetic methods based on cultures, (der Georg-August-Universitat Göttingen im Promotions program Biologie der Georg-August University School of Science (GAUSS), 40-60.

[21] D.M. John, A.J. Brook and B.A Whitton (2011). The freshwater algal flora of the British Isles: an identification guide to freshwater and terrestrial algae, Cambridge University Press, 1-30.

[22] K. Krammer and H. Lange-Bertalot (1991) Freshwater flora of Central Europe. Bacillariophyceae, Volume 2/4, Part 4:Achnanthaceae Critical Supplements to Navicula (Lineolatae) and Gomphonema Complete Catalog. Stuttgart: Gustav Fischer Verlag, German.

[23] K. Krammer and H. Lange-Bertalot (1991). Freshwater flora of Central Europe. Bacillariophyceae, volume 2/3, Part 3: Centrales, Fragillariaceae, Eunoticeae. Stuttgart: Gustav Fischer Verlag, German.

[24] K. Krammer and H. Lange-Bertalot (1999). Freshwater flora of Central Europe. Bacillariophyceae, volume 2/1, Part 1: Naviculaceae. Berlin: Spectrum Academicher Verlag, German.

[25] K. Krammer and H. Lange-Bertalot (1999). Freshwater flora of Central Europe. Bacillariophyceae, volume 2/2, Part 2: Bacillariaceae, Epithemiaceae, Surirellaceae, Berlin: Spectrum Academicher Verlag, German.

[26] R. Patrick and C.W. Reimer (1966). The diatoms of the United States, I. Acad. Sci, Philadelphia.

[27] R. Patrick and C.W. Reimer (1975). The diatoms of the United States, II. Acad. Sci, Philadelphia.

[28] G.W. Prescott (1975). Algae of the western Great Lakes area., Michigan State University. USA.

[29] J.D. Wehr and R.G. Sheath (2003). Freshwater algae of North America: ecology and classification. Boston.

[30] F. Maraşlığlu and A. Gönülol (2019). Turkish algae electronic publication. Çorum, Turkey. http://turkiyealgleri.hitit.edu.tr Accessed 20.06.2020.

[31] M.D. Guiry and G.M. Guiry (2019). Algae Base. Worldwide electronic publication, National University Of Ireland, Galway. http://www.algaebase.org Accessed 20.06.2020.

[32] SPSS INC (2004). Proffessional Statistics 13.0 SPSSINC, Chicago.

[33] C.J.F. Ter Braak and P. Šmilauer (2002). CANOCO Reference Manual and Cano Draw for Windows User's Guide: Software for Canonical Community Ordination (Version 4.5). Ithaca, NY, USA.

[34] C.S. Lin, T.L. Chou and J.T. Wu (2013). Biodiversity of soil algae in the farmlands of mid-Taiwan, Botan. Stud. 54, 1-12.

[35] V. Aysel (2005). Check-list of the freshwater algae of Turkey, J. Black Sea Mediterr. Environ. 11,1-124.

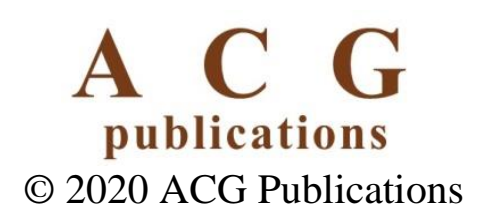

